\title{
Knowledge, perception and attitude about Crimean Congo Hemorrhagic Fever (CCHF) among medical and pharmacy students of Pakistan
}

\author{
Ali Ahmed*i(D, Maria Tanveer, Muhammad Saqlain and Gul Majid Khan
}

\begin{abstract}
Background: Crimean Congo Hemorrhagic (CCHF) is a deadly tick born disease caused by a virus of genus Nairovirus and is endemic in the Middle East, Asia, Africa, and Eastern areas of Europe. Pakistan is a CCHF endemic country with a constant threat of sporadic outbreaks. Health care workers are more prone to CCHF, hence, it is a prerequisite for members of the healthcare team to stay abreast with current knowledge and display positive attitude and perception. This study assessed the medical and pharmacy students' preparedness level in terms of CCHF control and management.
\end{abstract}

Methods: A total of 900 consenting students were selected randomly, who completed a predesigned and validated questionnaire which assessed the participant's general knowledge, emergency preparedness control and management of CCHF. Data were analyzed by SPSS (IBM SPSS version 21). For data analysis percentages, $P$-value, ttest, the independent sample mean, Whitney $U$ test, Kruskal-Wallis test, Logistic regression, and Spearman correlation were utilized.

Results: Among 900 study respondents, 68\% were females and 32\% were males, out of which physicians (MBBS) students were $48.4 \%$, and pharmacists students were $51.6 \%$. Majority of the respondents $39.9 \%$ were from age group of 22-25 years. Overall $43 \%$ healthcare students demonstrated good knowledge about disease causes, transmission, and treatment options. Additionally, $81 \%$ of the study participants showed positive attitude, whereas, $69 \%$ students demonstrated positive perceptions. The correlation coefficient showed positive correlation between attitude- perception $(r=0.268, p$ value $=0.000)$, knowledge- attitude $(r=0.234, p$ value $=0.000)$ and knowledgeperception $(r=0.257, p$ value $=0.000)$.

Conclusions: Knowledge gaps were observed which is alarming. These gaps were multifactorial and mainly due to lack of knowledge, poor motivation, and old syllabus which needs to be addressed. The study results show that it is crucial to evaluate current curriculum and also showing a dire need of awareness seminars, conferences workshops to highlight and educate about the current endemic disease to future health care professionals.

Keywords: CCHF, Healthcare professionals, Knowledge, Eid-ul-Azha, Pakistan's

\footnotetext{
* Correspondence: aliahmed@bs.qau.edu.pk

Department of Pharmacy, Quaid-I-Azam University, Islamabad 45320, Pakistan

(c) The Author(s). 2018 Open Access This article is distributed under the terms of the Creative Commons Attribution 4.0 International License (http://creativecommons.org/licenses/by/4.0/), which permits unrestricted use, distribution, and reproduction in any medium, provided you give appropriate credit to the original author(s) and the source, provide a link to the Creative Commons license, and indicate if changes were made. The Creative Commons Public Domain Dedication waiver (http://creativecommons.org/publicdomain/zero/1.0/) applies to the data made available in this article, unless otherwise stated.
} 


\section{Background}

Crimean Congo Hemorrhagic Fever (CCHF), a zoonotic viral hemorrhagic fever is a cause of significant morbidity and mortality; especially in underdeveloped countries. CCHFV is a member of the genus Nairovirus in the family Bunyaviridae. Basically, this disease is transmitted to humans by domestic animals and bite of an infected tick or via aerosol generated from infected animals' excreta. Human to human transmission occurs following contact with an infected person's blood, tissue or fluid discharge [1]. The vectors of this arthropod-borne disease are generally hard ticks of Ixodidae family, including some species of Rhipicephalus, Boophilus, Dermacentor and Hyalomma (in particular Hyalomma marginatum). Some species of Argasand Ornithodoros in Argasidae family have been reported to be infected The highly lethal virus is known for producing devastating outbreaks in humans which are very common in areas with developing healthcare systems such as in Africa, Middle East Asia, and Balkans. CCHF outbreaks constitute a threat to public health services because of its prolonged and intense course of infection. It has epidemic potential, high case fatality ratio (10-40\%), and difficulties in treatment and prevention. The Hyalomma tick bite infection has a high rate of nosocomial transmission especially due to direct human to human contact [2]. In Pakistan, sporadic outbreaks have been reported frequently, mostly due to contact with viremic livestock blood and nosocomial transmission. The hospital-borne spread has been associated with a lack of, or improper use of personal protective equipment when dealing with infected patients. It mostly occurs during early contact with an undiagnosed patient before taking appropriate protective measures [3]. The first case of CCHF in Pakistan was reported in 1976 and since then continuous cases of CCHF have been emerging throughout the country. In Pakistan 2010, outbreak in Khyber Pakhtunkhwa (KPK) province precipitated and 100 cases were reported and had a $10 \%$ fatality rate. Similarly on 11 July 2014, in Hayatabad Medical Complex (HMC), Kpk, 8 patients died, out of which 6 were Afghan nationals and a nurse [4]. Figure 1 Illustrates the prevalence of CCHF, from 2012 to 2016. In accordance with the ministry of the national institute of health, a total of 323 cases were confirmed [5]. Baluchistan remains the most affected province followed by KPK and Punjab. As Pakistan shares, a long border with Afghanistan so large number of patients from Afghanistan come to Pakistani hospitals especially in Peshawar, Quetta, and Islamabad making Congo infection of particular danger in these areas. Figure 1, shows that since the last 5 years about $47 \%$ of cases were reported from Baluchistan followed by $17 \%$ from Punjab $15 \%$ from KPK. Whereas, $14 \%$ cases were reported from Sindh followed by $4 \%$ from Islamabad and $2 \%$ from Federally Administered Tribal Areas (FATA) and lastly 1\% from Azad Jammu and Kashmir (AJK) [6].
In Pakistan, the overall environmental cycles are continuously subjected to major changes partly due to the effect of global warming. Such climatic changes affect the initiation and spread of disease outbreaks [7]. A similar trend of CCHF spread has been observed. During extremely hot weather the spread of CCHF experiences, a fall back followed by a subsequent rise during average weather. $\mathrm{CCHF}$ is an occupational disease for livestock workers, butchers, slaughterhouse workers, health care workers, animal husbandry workers and veterinarians who belong to a group of people at high risk of the disease in the endemic areas of CCHF [8]. The incidence rate increases by many folds during Eid ul Adha, a religious festival during which millions of animals are slaughtered $[6,9]$. As CCHF is a viral contagious endemic disease, cases of spread of this disease in healthcare professionals have also observed. In Quetta, a doctor died due to CCHF [10]. Another doctor died of Congo fever in Abbottabad [11]. A Surgeon and nurse from Bahawalpur hospital died of CCHF at Agha Khan University Hospital (AKUH) in 2016 [12].

Healthcare professionals are a high-risk group and the primary custodians for the provision of health-related treatments. Although education campaigns have increased their awareness regarding $\mathrm{CCHF}$ yet it remains unclear to what extent this knowledge can be put into practice and to what extent this practice actually reduces CCHF infection spread. Knowledge, attitude, and perception survey provide a suitable format to evaluate existing programs and to identify effective strategies for behavior change in society [13]. Therefore, it is necessary to evaluate the knowledge, attitude, and perceptions of future medical and pharmacy graduates. The main purpose of this study was to identify the knowledge, attitude, and perceptions of medical and pharmacy students about CCHF so a questionnaire assessing these aspects was designed and validated.

\section{Methods Study design}

A cross-sectional study was carried out amongst students of medical and pharmacy government and private universities of Pakistan from August 2016 to January 2017.

\section{Study location}

The study was conducted in Islamabad (capital of Pakistan), Rawalpindi, Lahore, and Faisalabad. Islamabad and Rawalpindi are located in the Potohar region of northern Punjab. The data was collected from government and private medical and pharmacy universities. From Islamabad data was collected from Riphah International University Islamabad, Quaid I Azam University Islamabad, Shaheed Zulfiqar Ali Bhutto Medical University Islamabad. From Rawalpindi data collected from Margalla Institute of Health Sciences and Rawalpindi medical college. From Lahore data was 


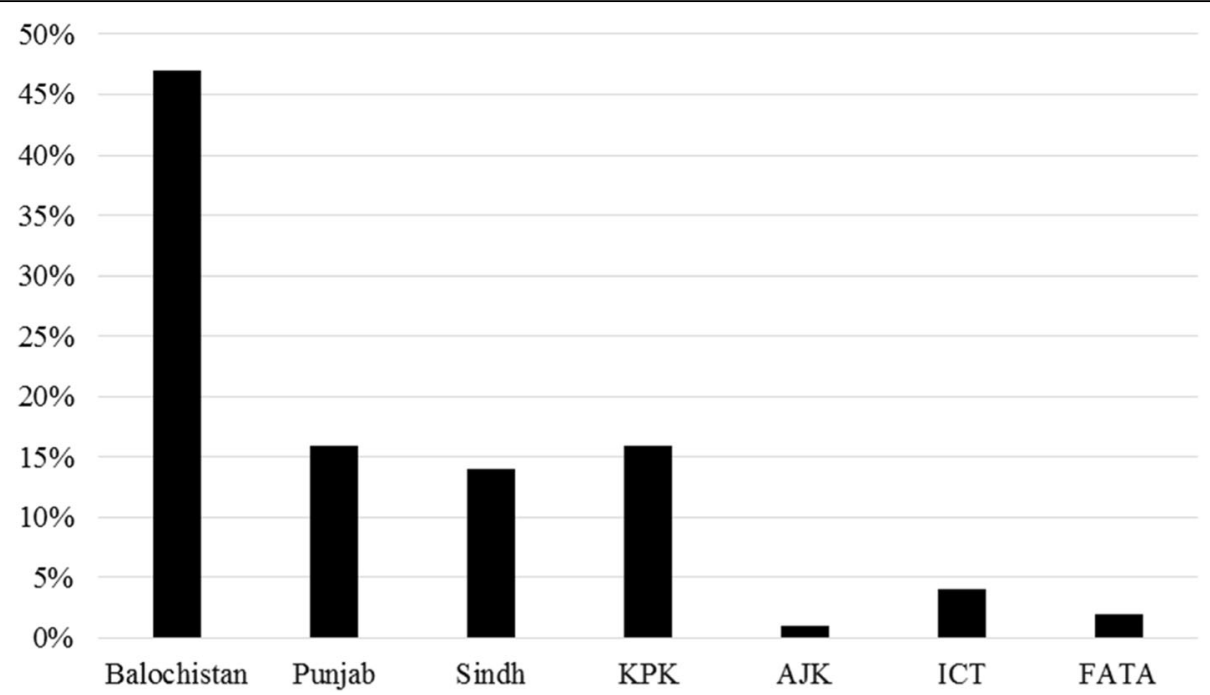

Fig. 1 Prevalence of CCHF in Pakistan. Shows the prevalence of CCHF in Pakistan. The highest prevalence is observed in the province of Baluchistan

collected from the University of Lahore, Akhtar Saeed Medical and Dental College, Allama Iqbal medical college, Superior University Lahore campus. From Faisalabad data was collected from Punjab Medical College Faisalabad.

\section{Ethical approval}

The ethical approval was obtained from Ethical and Research Board of Department of Pharmacy, Quaid-I-Azam University, Islamabad (Letter No. QAU/pharmacyDept/ 213). Further approval obtained from ethical and research committee of Pakistan Institute of Medical Sciences, PIMS (Letter No. F.1-1/2015/ERB/SZABMU/08/16) and other Universities and colleges allowed the research to be conducted on the basis of University approval letter.

\section{Sampling and data collection method}

A random sample technique was used to collect data from medical and pharmacy institutions. A self-developed pre-validated questionnaire along with written consent was administered among students at the end of lectures in their classrooms. After describing objective of study and nature of research students were asked to fill questionnaires in presence of the principal investigator. The consenting participants were guaranteed of confidentiality and informed of their right to withdraw from the research at any time when they wanted. Afterward filled questionnaires were collected from students by the investigator and later scoring was done. All poorly filled questionnaires were excluded from the study.

\section{Questionnaire development}

The questionnaire was developed after a thorough review of the literature and the items were evaluated and reviewed for validity by the research committee comprised of senior academic teachers pharmacist and physicians having relevant studies experience. The questionnaire consists of four parts assessing demographics, knowledge, attitude, and perceptions of students. The primary survey was performed a pilot study on 40 participants in order to achieve construct validation and to assess following aspects. All the Cronbach alpha values were above $0.50(0.565-0.871)$ which is an indication that the questionnaire is a significantly effective tool for measuring desired objectives and proves statistical validation. Questionnaire is included as Additional file 1.

\section{Study participants}

Study subjects were selected on basis of inclusion and exclusion criteria. According to inclusion criteria participants from4th year and final year MBBS, PharmD, MS/ MPhil and Ph.D. students of medical and pharmacy field were selected. Out of 1263 questionnaires were distributed in study participants and $981(78 \%)$ questionnaires were returned. While the questionnaires which were not appropriately filled like missing information were removed finally only 900 (71\%) questionnaire were included in the study.

\section{Data analysis}

Data analysis was performed using SPPS version 21.0 (IBM, Armonk, NY, USA). Descriptive statistics (frequencies, median and percentages) were calculated for data analysis. Normality of data is determined by using Kolmogorov-Smirnov test value $(P<0.001)$ as data contain more than 20,000 elements. Non-parametric test was used as inferential statistics tools. Independent sample Mann-Whitney $U$ tests were employed to determine variation in student's attitude and perceptions regarding Congo fever between gender, study course, marital status and college. Independent-sample Kruskal-Wallis tests were used to assess differences among age 
Table 1 Study population characteristics

\begin{tabular}{llll}
\hline Variables & Category & Frequency & Percent \\
\hline Gender & Female & 612 & 68.0 \\
& Male & 288 & 32.0 \\
Course of Study & Physician (MBBS) & 436 & 48.4 \\
& Pharmacist & 464 & 51.6 \\
Year of Study & PhD & 12 & 1.3 \\
& M.Phil. & 84 & 9.30 \\
& 5th year & 400 & 44.4 \\
Age & 4th year & 404 & 44.9 \\
& 18-21 & 292 & 32.4 \\
& 22-25 & 359 & 39.9 \\
Marital Status & 26 and above & 249 & 27.7 \\
& Yes & 368 & 40.9 \\
College & No & 532 & 59.1 \\
& Public Sector & 431 & 47.9 \\
& Private Sector & 469 & 52.1 \\
\hline
\end{tabular}

groups and study year of students with regard to their attitude and perceptions regarding Congo fever. Furthermore, logistic regression analysis was performed to explore factors responsible of good knowledge regarding Congo fever. Results are expressed as ORs accompanied by $95 \%$ CIs, and $P<0.05$ was used for statistical significance of differences. Pearson correlation test was performed to determine correlation between knowledge, perception and attitude items.

\section{Results}

\section{Characteristics of participants}

Total 900 students were investigated. Most of the participants were female $(n=612,68 \%)$ while $(n=288,32 \%)$ were males. The proportion of respondents includes $44.9 \%$ from $4^{\text {th }}$ year students, $44.4 \%$ from 5 th year students, 9.3\% from MPhil scholars, and 1.3\% from $\mathrm{PhD}$ scholars. Pharmacy students were over half $(n=464$,
$52.6 \%)$ of the total respondents. Most of the surveyed students ware unmarried $(n=532,59.1 \%)$ and were from the age group of $22-25$ ( $n=359,39.9 \%)$ Table 1 .

Figure 2, represents sources of information used by students in seeking information about CCHF. The majority of the respondents considered research articles as the major source of information, followed by radio, television, workshops \& conferences. Only 11\% considered brochures and newsletters to be the best source of information about CCHF.

\section{Knowledge about CCHF}

Table 2, represents the results obtained from the knowledge assessing items of the questionnaire. 24 questions were askedandmixed responses were observed amongst the respondents. More than (79\%) of the respondents correctly identified that contact with infected vector leads to the transmission of $\mathrm{CCHF}$, And almost equal proportion (79\%) of respondents correctly know about causative agent of CCHF. About more than half of the respondents (59\%), correctly identified the best prophylactic measure against CCHF and (35\%) gave an incorrect answer to the route of administration of anti-CCHF drug Ribavirin. Additionally, (66\%) study participants were also well familiar with the symptoms of CCHF viral disease and similarly (61\%) were familiar with standard treatment options available for CCHF. In addition, more than half of the respondents also incorrectly identified that water and air are causative factors for CCHF transmission. On the other hand, $81 \%$ of the respondents incorrectly identified the loading dose of ribavirin. About $62 \%$ of the respondents were unable to provide a correct answer about the most affected province of Pakistan. When the question was asked about the most affected months of the year only $21 \%$ of study participants could answer correctly. About $58 \%$ of study participants were well familiar with the

Newspapers and nonprofessionals megazines

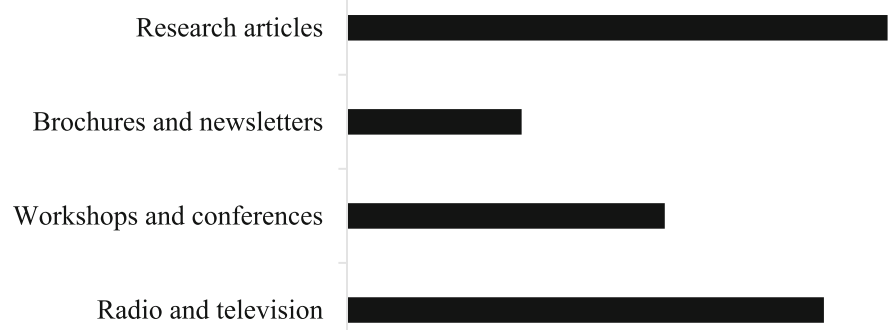

$\begin{array}{llllllll}0 \% & 5 \% & 10 \% & 15 \% & 20 \% & 25 \% & 30 \% & 35 \%\end{array} \quad 40 \%$

Fig. 2 Sources of CCHF. Shows the sources of information used by student healthcare professionals to seek guidance about CCHF 
Table 2 Students response to knowledge items

\begin{tabular}{|c|c|c|c|}
\hline \multirow[t]{2}{*}{ Sr. No. } & \multirow[t]{2}{*}{ Question } & \multicolumn{2}{|l|}{ Response } \\
\hline & & Correct & Incorrect \\
\hline 1 & Causing factor of CCHF & $712(79.10 \%)$ & $188(20.88 \%)$ \\
\hline 2 & spread of CCHF occurs through & $541(60.15 \%)$ & $359(39.88 \%)$ \\
\hline 3 & $\begin{array}{l}\text { Contact with infected vector can be } \\
\text { mode of Transmission to human }\end{array}$ & $712(79.10 \%)$ & $188(20.88 \%)$ \\
\hline 4 & $\begin{array}{l}\text { Contact with infected human blood } \\
\text { and body fluids can also be } \\
\text { transmission source }\end{array}$ & $747(83.00 \%)$ & 153(17\%) \\
\hline 5 & $\begin{array}{l}\text { Contact with animals cannot } \\
\text { transfer CCHF }\end{array}$ & $431(47.90 \%)$ & $469(52.11 \%)$ \\
\hline 6 & Most affected province of Pakistan? & $337(37.40 \%)$ & $563(62.55 \%)$ \\
\hline 7 & Most affected months of the year? & 197(21.90\%) & $703(78.10 \%)$ \\
\hline 8 & $\begin{array}{l}\text { CCHF can be transmitted through } \\
\text { percutaneous contact? }\end{array}$ & $637(70.08 \%)$ & $263(29.20 \%)$ \\
\hline 9 & $\begin{array}{l}\text { Most common cause of hospital } \\
\text { born Congo Infection? }\end{array}$ & $609(67.70 \%)$ & $291(32.30 \%)$ \\
\hline 10 & $\begin{array}{l}\text { The predominant symptoms } \\
\text { associated with CCHF are: }\end{array}$ & $594(66.00 \%)$ & $306(34.00 \%)$ \\
\hline 11 & $\begin{array}{l}\text { CCHF is highly symptomatic in } \\
\text { infected animals: }\end{array}$ & $312(34.70 \%)$ & $588(65.30 \%)$ \\
\hline 12 & Mortality rate of CCHF in Pakistan? & $415(46.10 \%)$ & $485(53.90 \%)$ \\
\hline 13 & $\begin{array}{l}\text { What diagnostic option (s) is } \\
\text { available for CCHF? }\end{array}$ & $522(58.00 \%)$ & $378(42.00 \%)$ \\
\hline 14 & $\begin{array}{l}\text { Standard treatment option available } \\
\text { for CCHF? }\end{array}$ & $547(60.80 \%)$ & $353(39.20 \%)$ \\
\hline 15 & $\begin{array}{l}\text { Best prophylactic measure(s) against } \\
\text { CCHF? }\end{array}$ & $531(59.00 \%)$ & $369(41.00 \%)$ \\
\hline 16 & Is CCHF a zoonotic disease? & $647(71.90 \%)$ & $253(28.10 \%)$ \\
\hline 17 & $\begin{array}{l}\text { Can CCHF be transmitted via air } \\
\text { and water? }\end{array}$ & $412(45.80 \%)$ & $488(54.20 \%)$ \\
\hline 18 & $\begin{array}{l}\text { Can CCHF be transferred through } \\
\text { social contacts }\end{array}$ & $333(37.00 \%)$ & $567(63.00 \%)$ \\
\hline 19 & $\begin{array}{l}\text { Can CCHF be completely cured } \\
\text { with medicine? }\end{array}$ & $229(25.40 \%)$ & $671(74.60 \%)$ \\
\hline \multirow[t]{2}{*}{20} & $\begin{array}{l}\text { Contact with feces, urine and saliva } \\
\text { of infected person can cause }\end{array}$ & & \\
\hline & CCHF? & $635(70.60 \%)$ & $265(29.40 \%)$ \\
\hline 21 & $\begin{array}{l}\text { Does avoiding mosquito's bites } \\
\text { prevents CCHF? }\end{array}$ & $418(46.40 \%)$ & $482(53.60 \%)$ \\
\hline 22 & Ribavirin is taken as orally? & $589(65.40 \%)$ & $311(34.60 \%)$ \\
\hline 23 & $\begin{array}{l}\text { Loading dose of Ribavirin taken for } \\
\text { CCHF is: }\end{array}$ & $170(18.90 \%)$ & 730(81.10\%) \\
\hline 24 & $\begin{array}{l}\text { Is there any vaccine available for } \\
\text { CCHF? }\end{array}$ & $565(62.80 \%)$ & $335(37.20 \%)$ \\
\hline
\end{tabular}

Knowledge section was assessed by giving a score of 1 to correct answer and 0 to wrong answer. A score of greater than equal to 14 was regarded as good and a score of less than 14 was regarded as poor

diagnostic options available for CCHF. Only $46 \%$ of study participants were well aware of the mortality rate of CCHF. Overall from knowledge section results, $43 \%$ of the students showed good knowledge, the criteria of which is correct response to 14 questions out of total 24. Among the participants, $58 \%$ medical students demonstrated good knowledge while only $28 \%$ pharmacy students demonstrated good knowledge Tables 2 and 3.

\section{Attitude about CCHF}

All respondents responded to all 6 parameters on their attitude of CCHF. From a maximum score of 5 (100\%) for positive attitude, respondents obtained a median score of 4 (IQR 1). These results demonstrate that participants have a strongly positive attitude regarding CCHF. About $71 \%(n=635)$ participants strongly agreed/agreed that early diagnosis can result in the rapid resolution of symptoms (median 4, IQR 2). Similarly, 67.5\% ( $n=608)$ participants strongly agreed/agreed that "supportive care helpful for CCHF" (median 4, IQR 2). On the other hand, 71\% $(n=666)$ of participants strongly agreed/agreed that "there should be isolated room for CCHF confirmed patient" (median 4, IQR 2), and 66.5\% $(n=598)$ of participants strongly agreed/ agreed that "lack of effective isolation state building facilities pose a significant risk to health professionals dealing with infected individuals" (median 4, IQR 2) Table 4.

\section{Perception about CCHF}

All participants supplied responses to all seven statements regarding their perception about CCHF. From a maximum score of $5(100 \%)$ for good perceptions, respondents obtained a median score of 4 (IQR 1). Therefore, participants demonstrated good perceptions regarding CCHF.About57.4\% $(n=517)$ participants strongly agreed/agreed that use of preventive medicines when dealing with patients suffering from highly contagious diseases is beneficial. $73.2 \%(n=672)$ Participants strongly agreed/agreed that all healthcare students and professionals should go for mandatory CCHF testing during sporadic outbreaks(median 4, IQR 1).71.6\% $(n=645)$ of participants strongly agreed/agreed that herders of animals, individuals working with livestock and slaughterhouse workers are at a higher risk of CCHF infection (median 4, IQR 1) Table 5.

\section{Differences in student's knowledge, attitude, and perception}

Variation in students' attitude and perception regarding Congo fever by characteristics were checked. According to independent-sample Mann-Whitney $U$ tests, professional degree (MBBS, PharmD) showed statistically significant differences $(P<0.05)$. MBBS students had higher attitude and perception scores (median $4, P<0.001$ ) than Pharmacy students. Those students which are studying in Public universities and colleges had a positive attitude (median $4, P<0.001$ ) than private university students. Married students had more positive attitude 
Table 3 Variation in respondents' knowledge by sample characteristics

\begin{tabular}{llll}
\hline Variables & Category & Knowledge & \\
\cline { 3 - 4 } & & Good knowledge & Poor knowledge \\
\hline Gender & Female & $277(45.26 \%)$ & $335(54.74 \%)$ \\
\multirow{2}{*}{ Profession } & Male & $109(37.97 \%)$ & $179(62.03 \%)$ \\
& Physician & $254(58.26 \%)$ & $182(41.74 \%)$ \\
Age & Pharmacist & $132(28.44 \%)$ & $332(71.55 \%)$ \\
& $18-21$ & $87(29.79 \%)$ & $205(70.21 \%)$ \\
Marital status & Married & $236(64.13 \%)$ & $132(35.87 \%)$ \\
& Single & $150(28.20 \%)$ & $382(71.80 \%)$ \\
College & Public Sector & $220(51.04 \%)$ & $211(48.96 \%)$ \\
& Private Sector & $166(35.39 \%)$ & $303(64.61 \%)$ \\
Study Year & Ph.D. & $04(33.30 \%)$ & $08(66.67 \%)$ \\
& M.Phil. & $54(64.29 \%)$ & $30(35.71 \%)$ \\
& 5th year & $153(38.25 \%)$ & $247(61.75 \%)$ \\
& 4th year & $175(43.32 \%)$ & $229(56.68 \%)$ \\
\hline
\end{tabular}

Knowledge section was assessed by giving a score of 1 to correct answer and 0 to wrong answer. A score of greater than equal to 14 was regarded as good and a score of less than 14 was regarded as poor

and perceptions (median $4, P<0.001$ ) than unmarried students. In independent-sample Kruskal-Wallis tests, we found that there was statistically significant variation between student's attitude and perception and different age groups (median $4, P<0.001$ ) while study year have statistically significant differences in the only perception of students (median $4, P=0.004$ ) Table 6.

Logistic regression analysis revealed that females (OR $1.45,95 \%$ CI $1.046-2.01 ; P=0.024)$, age group $22-25$ years (OR $0.48295 \%$ CI $0.324-0.716 P<0.001$ ), public sector universities (OR 2.083, 95\% CI 1.513-2.868; $P<$ 0.001 ), 5th year students (OR 0.546, 95\% CI $0.392-$ $0.762 ; P<0.001$ and married (OR 2.703, 95\% CI 1.8313.989; $P<0.001$ ) were the factors associated with the good knowledge regarding CCHF. Table 7.Significant linear positive correlation between attitude-perception $(r=0.268, p$ value $=.000)$, knowledge-attitude $(r=$ $0.234, p$ value $=.000)$, and knowledge-perception $(r=$ $0.257, p$ value $=.000)$ was observed Table 8.

\section{Discussion}

To the best of our knowledge, there is no reported study that has evaluated thoroughly knowledge, attitude, and perceptions of medical and pharmacy students about CCHF in Pakistan. In order to effectively deal with CCHF patients with minimum risks, healthcare professionals need to have good knowledge about precautionary measures like wearing of gloves, masks, protective clothing, goggles, disposables gowns and face shields before visiting patients. Transmission can occur through direct contact with infected blood, needle stick injuries, and contact with infected abraded skin and during disposal of infected waste. In Pakistan, a qualified general surgeon died of CCHF while dealing with CCHF patient due to nosocomial transmission. Many other examples of this type can be observed frequently throughout the world [12].

The previous such study conducted in students of a single college in Pakistan concluded that students have poor knowledge even about cause and source of transmission of $\mathrm{CHF}$ because respondents were nonhealthcare students like a business and social science students. The results of our study are batter to this study as the participants in our case are related to health care students [14]. When the results of our study were compared with the study conducted in healthcare professionals of Iran, similar results were found. But Iranian study demonstrated more knowledge of participants [15]. According to Iranian study when question CCHF can be transmitted through percutaneous contact from an infected individual was asked, $89.5 \%$ provided a correct answer while in our study $71 \%$ participants provided the correct answer. Similarly, in Turkish study 98.2\% healthcare provided a correct answer to this question [15, 16]. Furthermore, in our study, $53 \%$ of participants provided the wrong answer about vaccine availability. These results are confirmed with the similar study conducted previously in healthcare professionals of Baluchistan, Pakistan [17]. Baluchistan study also highlighted the major lacks of

Table 4 Students response to attitude items

\begin{tabular}{|c|c|c|c|c|c|c|}
\hline \multirow[t]{2}{*}{ Attitude assessing questions } & \multicolumn{5}{|l|}{ Response } & \multirow{2}{*}{$\begin{array}{l}\text { Median } \\
\text { (IQR) }\end{array}$} \\
\hline & $\mathrm{SD}(\%)$ & $\mathrm{D}(\%)$ & $N(\%)$ & $A(\%)$ & $\mathrm{SA}(\%)$ & \\
\hline Effect of early diagnosis on CCHF & $62(6.9)$ & 69(7.7) & $134(14.9)$ & $364(40.9)$ & $271(30.1)$ & $4(2)$ \\
\hline Is supportive care helpful for CCHF & $35(3.9)$ & $72(8)$ & $185(20.6)$ & $382(42.4)$ & $226(25.1)$ & $4(2)$ \\
\hline Are you at risk of contracting CCHF? & $31(3.4)$ & $91(10.1)$ & $180(20)$ & $350(38.9)$ & $248(27.6)$ & $4(2)$ \\
\hline Do you feel concerned while dealing with infected individuals? & $62(6.9)$ & 156(17.3) & $221(24.6)$ & $354(39.3)$ & $107(11.9)$ & $4(1)$ \\
\hline Is Health care system effectively equipped? & $102(11.3)$ & $313(34.8)$ & $175(19.4)$ & $259(28.8)$ & $51(5.7)$ & $3(2)$ \\
\hline Should there be an isolated room for CCHF confirmed patient? & $39(4.3)$ & $84(9.3)$ & 138(15.3) & $352(36.1)$ & $314(34.9)$ & $4(2)$ \\
\hline Attitude score overall & & & & & & $4(1)$ \\
\hline
\end{tabular}


Table 5 Students response to perception items

\begin{tabular}{|c|c|c|c|c|c|c|}
\hline \multirow[t]{2}{*}{ Perception assessing questions } & \multicolumn{5}{|c|}{ Response } & \multirow{2}{*}{$\begin{array}{l}\text { Median } \\
\text { (IQR) }\end{array}$} \\
\hline & $\mathrm{SD}(\%)$ & $\mathrm{D}(\%)$ & $\mathrm{N}(\%)$ & $A(\%)$ & $\mathrm{SA}(\%)$ & \\
\hline Will you follow standard procedures to minimize the risk of transmission of infection? & $32(6.6)$ & $67(14.02)$ & $96(20.08)$ & $250(52.3)$ & $33(6.9)$ & $4(1)$ \\
\hline $\begin{array}{l}\text { Are you equipped will necessary skills to protect yourself while dealing with CCHF } \\
\text { patients? }\end{array}$ & $69(7.7)$ & 136(15.1) & 185(20.6) & $423(47)$ & $87(9.7)$ & $4(1)$ \\
\hline Use of preventive medicines while dealing with CCHF patients? & $49(5.4)$ & $159(17.7)$ & $175(19.4)$ & $417(46.3)$ & $100(11.1)$ & $4(1)$ \\
\hline You have valuable sources of information for CCHF? & $53(5.9)$ & $152(16.9)$ & $195(21.7)$ & $442(49.1)$ & $58(6.4)$ & $4(1)$ \\
\hline $\begin{array}{l}\text { All healthcare professionals should go for mandatory CCHF testing during sporadic } \\
\text { outbreaks }\end{array}$ & $20(2.2)$ & $80(8.9)$ & $128(14.2)$ & $575(63.9)$ & $97(10.8)$ & $4(1)$ \\
\hline Having pets increases risk of CCHF? & $36(4)$ & $101(11.2)$ & $190(21.1)$ & $444(49.3)$ & 129(14.3) & $4(1)$ \\
\hline Animal herders are at additional risk of contracting disease & $51(5.7)$ & $73(8.1)$ & $131(14.6)$ & $426(47.3)$ & 219(24.3) & $4(1)$ \\
\hline Overall Perception score & & & & & & $4(1)$ \\
\hline
\end{tabular}

knowledge, especially in preventive and burial procedures. Knowledge about the causes of disease was good but major deficiency was observed in transmission, epidemiology, and treatment of disease. Table 3, overall female healthcare students have more knowledge then male participants. The reason might be the hard work and more interest of female students in health care practices. Knowledge of healthcare students increased with age and married students are quite good in this as they might attend number of clinical rounds, conferences, and workshops. so they have more knowledge about the disease [18]. Medical students knowledge was significantly better than that of pharmacist students [19]. This could be possibly explained by the current health care system in Pakistan where medical students are seen as more clinically oriented professionals than other professionals because of their in-depth clinical training and more opportunities for professional development. However, it is equally important to educate Pharmacist, as they are at equal risk of acquiring and transmitting infections such as CCHF. There is a need to encourage these workers to educate themselves with an updated knowledge of infections and other healthcare issues by participating in educational and related programs.

More than $70 \%$ healthcare professionals favored there should be an isolated room for the CCHF confirmed patients. These results are consistent with the studies previously done in healthcare professionals in Iran. These results were also consistent with the results of a study conducted in rural Georgian village [20]. However, in one question highly negative atti-

Table 6 Variation in Students attitude and perception regarding Congo fever by characteristics

\begin{tabular}{|c|c|c|c|c|c|c|c|}
\hline \multirow[t]{2}{*}{ Variables } & \multirow[t]{2}{*}{ Category } & \multicolumn{3}{|l|}{ Attitude } & \multicolumn{3}{|c|}{ Perception } \\
\hline & & Median (IQR) & Rank & $P$-value & Median & Rank & $P$-Value \\
\hline \multirow[t]{2}{*}{ Gender $^{a}$} & Male & $4(1.5)$ & 442.9 & 0.536 & $4(1)$ & 440.2 & 0.345 \\
\hline & Female & $4(1.0)$ & 454.1 & & $4(1)$ & 455.4 & \\
\hline \multirow[t]{2}{*}{ Profession $^{a}$} & MBBS & $4(1)$ & 537.1 & $<0.001$ & $4(1)$ & 480.2 & $<0.001$ \\
\hline & Pharmacist & $4(1)$ & 369.1 & & $4(1)$ & 422.6 & \\
\hline \multirow[t]{3}{*}{$\mathrm{Age}^{\mathrm{b}}$} & $18-21$ & $4(1)$ & 370.5 & $<0.001$ & $4(1)$ & 397.8 & $<0.001$ \\
\hline & $22-25$ & $4(1)$ & 412.7 & & $4(1)$ & 438.6 & \\
\hline & 26 and above & $4(1)$ & 598.8 & & $4(0)$ & 529.5 & \\
\hline \multirow[t]{2}{*}{ College ${ }^{a}$} & Public & $4(1.5)$ & 497.1 & $<0.001$ & $4(1)$ & 452.3 & 0.816 \\
\hline & Private & $4(1)$ & 407.7 & & $4(1)$ & 448.8 & \\
\hline \multirow[t]{2}{*}{ Marital status ${ }^{a}$} & Married & $4(1)$ & 555.6 & $<0.001$ & $4(0)$ & 516.3 & $<0.001$ \\
\hline & Unmarried & $4(1)$ & 377.8 & & $4(1)$ & 416.1 & \\
\hline \multirow[t]{4}{*}{ Study year ${ }^{b}$} & $\mathrm{PhD}$ & $4(1)$ & 401.5 & 0.468 & $4(1)$ & 425.3 & 0.004 \\
\hline & M.Phil. & $4(0)$ & 460.8 & & $4(0)$ & 535.1 & \\
\hline & 5th Year & $4(1.5)$ & 462.5 & & $4(1)$ & 437.1 & \\
\hline & 4th Year & $4(1)$ & 437.9 & & $4(1)$ & 446.2 & \\
\hline
\end{tabular}

${ }^{a}$ Independent sample Mann-Whitney $U$ test

${ }^{b}$ Independent sample kruskall-wallis test

$P<0.05$ (2-tailed) considered significant 
Table 7 Logistic regression analysis for factor associated with Good knowledge regarding Congo fever

\begin{tabular}{|c|c|c|c|c|}
\hline \multirow[t]{2}{*}{ Variables } & \multicolumn{2}{|l|}{ Knowledge } & \multirow{2}{*}{$\begin{array}{l}\text { Odds ratio } \\
(95 \% \mathrm{Cl})\end{array}$} & \multirow[t]{2}{*}{$P$-Value } \\
\hline & Good knowledge & Poor knowledge & & \\
\hline \multicolumn{5}{|l|}{ Gender } \\
\hline Female & 277 (45.26\%) & 335 (54.74\%) & $1.45(1.046-2.01)$ & 0.026 \\
\hline Male & 109 (37.97\%) & 179 (62.03\%) & Reference & - \\
\hline \multicolumn{5}{|l|}{ Profession } \\
\hline Physician & $254(58.26 \%)$ & $182(41.74 \%)$ & $1.413(0.974-2.049)$ & 0.068 \\
\hline Pharmacist & 132 (28.44\%) & $332(71.55 \%)$ & Reference & - \\
\hline \multicolumn{5}{|l|}{ Age } \\
\hline $18-21$ & 87 (29.79\%) & 205 (70.21\%) & $0.337(0.217-0.523)$ & $<0.001$ \\
\hline $22-25$ & 129 (35.90\%) & 230 (64.07\%) & $0.482(0.324-0.716)$ & $<0.001$ \\
\hline $26<$ & 170 (68.27\%) & $79(31.73 \%)$ & Reference & - \\
\hline \multicolumn{5}{|l|}{ Marital status } \\
\hline Married & $236(64.13 \%)$ & $132(35.87 \%)$ & $2.703(1.831-3.989)$ & $<0.001$ \\
\hline Single & $150(28.20 \%)$ & 382 (71.80\%) & Reference & - \\
\hline \multicolumn{5}{|l|}{ College } \\
\hline Public Sector & 220 (51.04\%) & $211(48.96 \%)$ & $2.083(1.513-2.868)$ & $<0.001$ \\
\hline Private Sector & 166 (35.39\%) & 303 (64.61\%) & Reference & - \\
\hline \multicolumn{5}{|l|}{ Study Year } \\
\hline Ph.D & $04(33.30 \%)$ & $08(66.67 \%)$ & $0.320(0.084-1.220)$ & 0.095 \\
\hline M.Phil & $54(64.29 \%)$ & $30(35.71 \%)$ & $1.389(0.808-2.389)$ & 0.235 \\
\hline 5th year & 153 (38.25\%) & 247 (61.75\%) & $0.546(0.392-0.762)$ & $<0.001$ \\
\hline 4 th year & $175(43.32 \%)$ & $229(56.68 \%)$ & Reference & \\
\hline
\end{tabular}

Knowledge section was assessed by giving a score of 1 to correct answer and 0 to wrong answer. A score of greater than equal to 14 was regarded as good and a score of less than 14 was regarded as poor

$\mathrm{OR}=$ Odds Ratio

$P<0.05$ (2-tailed) considered significant

tude was observed like commenting on the statement 'is healthcare system of Pakistan is effectively equipped with the treatment facilities or not' only about $34 \%$ participants agreed with the statement while the majority of participants opposed the statement with a negative attitude. This result is consistent with these studies [16, 21]. Findings of these results revealed that with huge positive attitude if healthcare professionals equip themselves with the basic knowledge of CCHF disease, better treatment of patients can be done with limited resources.

Among the participants 59\% agreed on to follow standard procedures to minimize the risk of infections, $57 \%$ students

Table 8 Correlation between scores of knowledge, attitude, and perception

\begin{tabular}{lll}
\hline Variable & Correlation Coefficient & $P$-Value \\
\hline Attitude-Perception & $0.268^{\mathrm{a}}$ & .000 \\
Knowledge-Attitude & $0.234^{\mathrm{a}}$ & .000 \\
Knowledge-Perception & $0.257^{\mathrm{a}}$ & .000 \\
\hline
\end{tabular}

${ }^{a}$ Correlation significant at 0.01 level ( 2 tailed) agreed that they are effectively equipped with necessary observing skills, 57\% participants agreed with the use of preventive medicine and $56 \%$ showed positive response about whether they have valuable sources of information. These results are somewhat similar to the studies conducted previously in different countries [20,22]. Majority of participants agreed that animal herders and pets increased the risk of CCHF infection just like Turkish study [23]. The mean attitude and perceptions of the participants were positive. The attitudes and perceptions of the physician students were more positive than that of pharmacist students. This finding could be interpreted to mean that physician students are more aware of their patient's clinical condition and are responsible for counseling patients, which reflects positivity in their attitudes and perceptions about the disease.

Although the national institute of Health (NIH), Pakistan has already advised that healthcare professionals are at increased risk of contracting the disease. Despite the welcoming and positive attitude and perceptions of students towards CCHF, knowledge of students about CCHF was very poor. Possible reasons include lack of educational programs necessarily dealing the outbreak of disease. 


\section{Strengths and limitations of the study}

The strength of this study is that it has focused on the area where not much literature is available from Pakistan. The results of this study can help the stakeholders and other health officials to evaluate the effectiveness of their policies about CCHF. The large sample size and the fact that a fairly high proportion of the total number of students from private $(52.1 \%)$ and public (47.9\%) colleges from the capital city and Punjab province are included to strengthen the validity of the research. However, since Pakistan is a country with huge regional differences in socioeconomic and health status, our results may not be representative of all medical and pharmacy students in the country. The reliability and validity of the survey are strengthened through the previous testing of the instrument. However, we cannot ignore the tendency of participants to provide more socially desirable responses.

\section{Conclusion}

The current study has its implications in relation to policy and practice as it provides a current snapshot of the knowledge, attitude, and perception about a life-threatening zoonotic endemic among future health care professionals. The findings of this study indicate that the student HCWs' knowledge about CCHF was not optimal; however, their attitudes about CCHF were positive. Future studies should be conducted nationwide to validate these results. Interventions should be customized to target areas where participants showed a lack of knowledge and negative attitudes. Study results demonstrate that it is crucial to evaluate current curriculum and there is dire need of awareness seminars, conferences, and workshops about current endemic diseases to future health care professionals.

\section{Additional file}

Additional file 1: Questionnaire used in study. (DOCX 20 kb)

\begin{abstract}
Abbreviations
AJK: Azad Jammu and Kashmir; AKUH: Agha Khan University Hospital; CCHF: Crimean Congo Hemorrhagic Fever; CCHFV: Crimean Congo Hemorrhagic Fever Virus; FATA: Federally Administered Tribal Areas; HCWs: Healthcare Workers; KPK: Khyber Pakhtunkhwa
\end{abstract}

\section{Acknowledgements}

The authors would like to extend heartfelt graciousness to all the Students and teachers who provided support at every step of the research.

\section{Funding}

The authors declare that they have not received any direct or indirect funding from any organization.

\section{Availability of data and materials}

The data sets used or analyzed during the current study available from the corresponding author upon reasonable request. Questionnaire used in this study is included as Additional file 1.

\section{Authors' contributions}

The manuscript idea, concept, writing, and layout was done by AA. MT provided critical help in writing, statistical and layout designing. MS provided critical input regarding statistical analysis at every step of the manuscript writing process. GMK was main facilitator, proof read the manuscript and provided input in writing. All authors read and approved the final manuscript.

\section{Ethics approval and consent to participate}

The ethics approval was obtained from Ethical and Research Board of Department of Pharmacy, Quaid-I-Azam University, Islamabad (Letter No. QAU/pharmacyDept/213). The approval was also obtained from selected hospitals, Pakistan Institute of Medical Sciences, PIMS (Letter No. F.1-1/2015/ ERB/SZABMU/08/16) and other hospitals allowed the research to be conducted on the basis of university ethical letter.

The selected participants were asked to participate and were required to sign an informed consent form.

\section{Consent for publication}

Not applicable.

\section{Competing interests}

The authors declare that they have no competing interests.

\section{Publisher's Note}

Springer Nature remains neutral with regard to jurisdictional claims in published maps and institutional affiliations.

Received: 20 August 2018 Accepted: 22 November 2018

Published online: 03 December 2018

\section{References}

1. Salimi M, Afshar AA, Limoee M, Babakhani S, Chatrabgoun O, Hanafi-Bojd AA, Nutifafa GGJAPJoTB: Knowledge, attitude and practice of healthcare workers concerning Crimean-Congo hemorrhagic fever in Western Iran. 2016, 6(6):546-550.

2. Dowall SD, Carroll MW, Hewson R. Development of vaccines against CrimeanCongo haemorrhagic fever virus. Vaccine. 2017.

3. Mallhi TH, Khan YH, Tanveer N, Khan AH, Qadir Ml. Commentary: surveillance of Crimean-Congo Haemorrhagic fever in Pakistan. Front Public Health. 2017:5:132

4. Khan H. Stemming outbreaks: Eighth patient dies of Congo hemorrhagic fever at HMC: The Express Tribune; 2014.

5. NIH. SEASONAL AWARENESS AND ALERT LETTER (SAAL), 38th issue, Governmant of Pakistan. https://www.nih.org.pk/.

6. SEASONAL AWARENESS AND ALERT LETTER (SAAL), 38th issue, Governmant of Pakistan, https://www.nih.org.pk/.

7. Ahmed A, Tanveer M, Khan G, Imran MJPh: Dengue fever again in Pakistan: are we going in the right direction? 2017, 152:153-156.

8. Zakham F, Al-habal M, Taher R, Alaoui A, El Mzibri MJPntd: Viral hemorrhagic fevers in the Tihamah region of the western Arabian Peninsula. 2017, 11(4): e0005322.

9. Khader YS, Abdelrahman M, Abdo N, Al-Sharif M, Elbetieha A, Bakir H, Alemam R. Climate change and health in the eastern Mediterranean countries: a systematic review. Rev Environ Health. 2015;30(3):163-81.

10. Dawn: Surgeon dies of Congo fever. In: Dawn: https://www.dawn.com/ news/660423. Quetta; 2011.

11. News: Tests confirm Abbottabad doctor died of Congo fever. In: The News: http://thenews.com.pk/archive/print/262150-tests-confirm-abbottabaddoctor-died-of-congo-fever. 2010

12. Bhatti MW: Surgeon from Bahawalpur hospital dies of CCHF at AKUH. In: The News: https://www.thenews.com.pk/print/138904-Surgeon-fromBahawalpur-hospital-dies-of-CCHF-at-AKUH. 2016.

13. Organization WH: A guide to developing knowledge, attitude, and practice surveys Switzerland. 2008.

14. SRH MA, Parveen F, Khan U, Alvi I, Nasir A, Zahid H, Zaeem N, Batool HI Liaquat $H$. evaluation of knowledge, attitude and perception towards Crimean Congo hemorrhagic fever among students: a cross sectional study. Electronic Journal of Biology. 2016;12(4):456-63. 
15. Rahnavardi M, Rajaeinejad M, Pourmalek F, Mardani M, Holakouie-Naieni K Dowlatshahi S. Knowledge and attitude toward Crimean-Congo haemorrhagic fever in occupationally at-risk Iranian healthcare workers. J Hosp Infect. 2008:69(1):77-85.

16. Yolcu S, Kader C, Kayipmaz AE, Ozbay S, Erbay A. Knowledge levels regarding Crimean-Congo hemorrhagic fever among emergency healthcare workers in an endemic region. Journal of clinical medicine research. 2014;6(3):197.

17. Sheikh NS, Sheikh AS, Sheikh AA. Knowledge, attitude and practices regarding Crimean-Congo haemorrhagic fever among healthcare workers in Balochistan. Headache. 2004:30:20.

18. Munnell AH, Sass SA, Soto M. Employer attitudes toward older workers: survey results: Center for Retirement Research at Boston College Chestnut Hill, MA; 2006.

19. Suchitra J, Devi NL. Impact of education on knowledge, attitudes and practices among various categories of health care workers on nosocomial infections. Indian J Med Microbiol. 2007;25(3):181.

20. Greiner AL, Mamuchishvili N, Kakutia N, Stauffer K, Geleishvili M, Chitadze N, Chikviladze T, Zakhashvili K, Morgan J, Salyer SJ. Crimean-Congo hemorrhagic fever knowledge, attitudes, practices, risk factors, and Seroprevalence in rural Georgian villages with known transmission in 2014 PLoS One. 2016;11(6):e0158049.

21. Pappas G, Akhtar T, Gergen PJ, Hadden WC, Khan AQ. Health status of the Pakistani population: a health profile and comparison with the United States. Am J Public Health. 2001:91(1):93.

22. Ozer A, Miraloglu M, Ekerbicer HC, Cevik F, Aloglu N. Knowledge levels about Crimean-Congo hemorrhagic fever among midwifery and nursing students in Kahramanmaras. Turkey Southeast Asian Journal of Tropical Medicine and Public Health. 2010:41(1):77.

23. Sisman A. Epidemiologic features and risk factors of Crimean-Congo hemorrhagic fever in Samsun Province, Turkey. Journal of epidemiology. 2013;23(2):95-102

Ready to submit your research? Choose BMC and benefit from:

- fast, convenient online submission

- thorough peer review by experienced researchers in your field

- rapid publication on acceptance

- support for research data, including large and complex data types

- gold Open Access which fosters wider collaboration and increased citations

- maximum visibility for your research: over $100 \mathrm{M}$ website views per year

At $\mathrm{BMC}$, research is always in progress.

Learn more biomedcentral.com/submissions 